\title{
Accident Statistics and Key Performance Indicators in Marine Offshore Industry
}

\section{Statistika nezgoda i ključni pokazatelji u pomorskoj odobalnoj industriji}

\author{
Tatjana Stanivuk \\ University of Split \\ Faculty of Maritime Studies \\ e-mail: tatjana.stanivuk@pfst.hr
}

\author{
Rino Bošnjak \\ University of Split \\ Faculty of Maritime Studies \\ e-mail: rbosnjak@pfst.hr
}

\author{
Branko Franić \\ University of Split \\ Faculty of Maritime Studies \\ e-mail:bfranic@pfst.hr
}

\author{
DOI 10.17818/NM/2019/1.3 \\ UDK 334.726 \\ Preliminary communication / Prethodno priopćenje \\ Paper accepted / Rukopis primljen: 18. 10. 2018
}

\section{KEY WORDS}

offshore maritime companies accident statistics performance indicators

wind power plants installed in marine environment. This study focuses on oil and offshore companies. Over the past decades this industry has been faced with responsible management requirements, which in practice implies the implementation of measures aiming at prevention of ecological damage to the marine and coastal environment and subsoil. The International Marine Contractors Association (IMCA) produces combined reports on offshore accidents and sets the excellence criteria based on statistical data. The companies comply with the responsible management principles which results in positive image within the industry and on the international market. This study has been based on accident reports for 264 offshore companies. Comparison of the average results in the observed group with the results of one selected offshore company has provided insights into deviations from the group average indicators. This has enabled an analysis of the causes of deviations at the selected company. In addition, the results have been studied from the standpoint of the sustainable growth and development of the company.

\section{Sažetak}

Pomorski promet okosnica je svjetske trgovine. Jedan dio odnosi se na odobalne pomorske kompanije. Ove kompanije obavljaju specijalizirane zadaće i aktivnosti povezane s eksploatacijom podmorja zemnim plinom i naftom ili vjetroelektrana koje se instaliraju u morskom okruženju. Uovom radu ciljana skupina upravo su odobalne pomorske kompanije zanaftu izemniplin. Posljednjih desetljeća ovaje industrija izložena zahtjevima odgovornog poslovanja, što u praksi podrazumijeva implementaciju zaštitnih mjera za sprječavanje ekološke štete morskog te priobalnog okoliša i podmorja. Međunarodna pomorska udruga poduzetnika (engl. The International Marine Contractors Association - IMCA) izrađuje skupna izvješća o nezgodama za odobalne kompanije i na temelju statističkih podataka postavlja kriterije izvrsnosti. Kompanije prihvaćaju odgovorno poslovanje, a rezultat je pozitivan imidž u branši i na međunarodnom tržištu. U ovom radu istraživanje se temelji na podatcima o pomorskim nezgodama za 264 pomorske odobalne kompanije. Usporedbom prosječnih rezultata za promatranu skupinu kompanija s rezultatima (jedne) izabrane odobalne kompanije, došlo se do uvida o odstupanjima u odnosu na grupne pokazatelje. Shodno nalazu, istraženi su uzroci odstupanja kod promatrane odobalne pomorske kompanije. Isto je promatrano i sa stajališta održivog rasta i razvoja ove kompanije.

\section{INTRODUCTION / Uvod}

Much attention has been drawn to the environment issues and responsible management over the past several decades. The transport of goods and passengers, as an essential aspect of the global networking, complies with the standards referring to the safety, speed and capacity of ships. However, accidents having long-term impacts on marine environment continue to occur, despite the development of maritime transport technologies.
The companies that are liable face huge indemnities, negative publicity and potential business failure. Prevention of such scenarios lies in the implementation of safety measures and transparent reporting on potential hazards and on the introduced risk avoiding measures.

Accident risk is always present in offshore operations. The purpose of this study is to explore the accidents occurring at 
the offshore companies that are members of the International Marine Contractors Association (IMCA). This source provides a consistent collection of accident data supplied by all companies within the system. The safety of business operation implies responsible management that is harmonised with the environmental standards and responsible attitude towards the users of such services. It is assumed that the companies having low accident risk occurrence records will attract subcontractors and service users and consequently increase their market share on the competitive market of maritime offshore operations [1].

This paper discusses offshore operation accidents with a particular focus on statistics and the deviations of the key performance indicators between a selected offshore company and the average resulting from the analysis of accidents at 264 offshore companies within IMCA.

\section{ACCIDENT STATISTICS / Statistika nezgoda}

One of the essential indicators of an offshore company performance is the consistent implementation of preventive measures [2] aiming at marine pollution prevention. A systemic approach to the prevention of marine pollution from ships enables the consideration of the marine transport system as a whole and makes the management of this system's units easier. The harmful impact of pollutants on humans is the essential reason for studying them, observing their distribution in the biosphere, i.e. migrations in natural media and, in particular, controlling their emissions from various anthropogenic sources [3].

The statistics of accidents at maritime offshore companies indicates the deviations in time intervals and per vessel. It feeds on the data supplied by internal audits and follow-up of the accidents that took place as well as those that were avoided. This enables a thorough insight into the state of organisation factors with an emphasis on human and material resources. For the purpose of this study, the analysis of accidents at maritime offshore companies has been performed on the basis of two data sources.

The first source of information refers to the reports on offshore accidents supplied by IMCA. These data refer to the period 2009-2016 and present an overall situation that includes the entire IMCA population of 264 offshore companies.

The second source refers to the data supplied by a selected and observed maritime offshore company over the period 2009-2017.

The techniques used while gathering the information from IMCA and the selected offshore company were harmonised, as they are based on the same survey form that the selected offshore company submitted to IMCA annually. There were some constraints regarding the time framework as the IMCA did not have available data for the year 2017.

\subsection{Reference data / Podatci o istraživanju}

In a wide sense, a maritime accident is any extraordinary occurrence with harmful outcomes that directly put human life, property or environment at risk [4]. Accident statistics and key indicators of the performance of offshore companies designate the positioning of companies on the maritime market. They also allow detailed insights into the category and type of accidents that occurred or may have occurred. For the purpose of improving the business performance of its members (companies engaged in maritime, offshore and subsoil operations), IMCA examines the operation safety rate by using the survey questionnaires and, in this way, checks the compliance with legislation and safety requirements.

It has been already explained that this study is based on the data supplied by $\mathrm{N}=264$ offshore companies and that the overall population includes one company whose name is not revealed for the purpose of identity protection [5]. The study brings an analysis of correlation between the accidents data at this company and the overall data that refer to the entire IMCA population [6]. The statistical values that have been observed, measured and compared include:

Incident - an uncontrolled or unplanned event, resulting in injury or fatality.

Work Injury - any sign or symptom of physical damage or impairment to any part of the body directly resulting from an incident, regardless of the length of time between the incident and the appearance of the injury.

Fatality - a death directly resulting from a work injury regardless of the length of time between the injury and death. Permanent Total Disability (PTD) - any work injury which incapacitates an employee permanently (e.g. loss of limbs, permanent brain damage, and loss of sight) and precludes the individual from working either at sea or ashore.

Permanent Partial Disability (PPD) - any work injury which incapacitates an employee permanently (e.g. loss of limbs, permanent brain damage, and loss of sight) but does not preclude the individual from working at another position either at sea or ashore.

Lost Workday Case (LWC) - an injury which results in an individual being unable to carry out any of his/her duties or to return to work on a scheduled work shift on the day following the injury.

Lost Time Injuries (LTI) - are the sum of Fatalities, Permanent Total Disabilities (PTD), Permanent Partial Disabilities (PPD) and Lost Workday Cases (LWC), i.e. this value is calculated according to the formula (1):

$L T I=$ Fatalities $+P T D+P P D+L W C$

Lost time incident frequency rate (LTIFR) is the number of LTI per unit exposure hours and is calculated by the formula (2):

$L T I F R=\frac{L T I \cdot 1.000 .000}{\text { Exposure hours }}$

Restricted Work Case (RWC) - an injury which results in an individual being unable to perform all normally assigned work functions during a scheduled work shift or being assigned to another job on a temporary or permanent basis. Medical Treatment Case (MTC) - any work-related injury, illness or loss of consciousness (unless due to ill health), requiring more than first aid treatment by a physician, dentist, surgeon or registered medical personnel.

Total Recordable Incidents (TRI) - are the sum of all Fatalities, Lost Time Injuries, Restricted Work Cases and Medical Treatment Cases. This value is calculated by the formula (3):

$T R I=L T I+R W C+M T C$

Total recordable incident frequency rate (TRIFR) is calculated as the sum of recordable incidents (all Fatalities, Lost Time Injuries, Restricted Work Cases and Medical Treatment Cases) per unit exposure hours, i.e. according to the formula (4): 


$$
T R I F R=\frac{T R I \cdot 1.000 .000}{\text { Exposure Hours }}
$$

- First Aid Case (FAC) - any one-time treatment or minor injuries such as bruises, scratches, cuts, burns, etc. The first aid may or may not be administered by a physician or registered professional.

- Near Miss - event or sequence of events which did not result in an injury but which, under slightly different conditions, could have done so.

- Exposure Hours - 24 hours per day while serving on board.

\subsection{Correlation statistics of the gathered accident data / Statistika korelacije prikupljenih podataka o nezgodama}

Table 1 presents the overall data for 264 companies over the period 2009.-2016. for the variables [7]:

1. FAR (Fatal accident rate),

2. LTIFR (Lost time incident rate), and

3. TRIFR (Total recordable incident rate).

Table 1 IMCA: accidents at maritime offshore companies ( $\mathrm{N}=264$ ) from 2009 to 2016

Tablica 1 IMCA: nezgode kod odobalnih pomorskih kompanija $(N=264)$ od godine 2009. do 2016.

\begin{tabular}{|c|c|c|c|}
\hline IMCA & FAR IMCA & LTIFR IMCA & TRIFR IMCA \\
\hline 2009 & 0 & 1.34 & 7.86 \\
\hline 2010 & 0 & 1.62 & 6.29 \\
\hline 2011 & 10.35 & 1.39 & 4.86 \\
\hline 2012 & 0 & 1.24 & 5.13 \\
\hline 2013 & 0 & 1.55 & 4.04 \\
\hline 2014 & 22.46 & 1.71 & 4.46 \\
\hline 2015 & 11.81 & 1.56 & 4.18 \\
\hline 2016 & 2.73 & 1.24 & 6.43 \\
\hline 2017 & $/$ & $/$ & $/$ \\
\hline
\end{tabular}

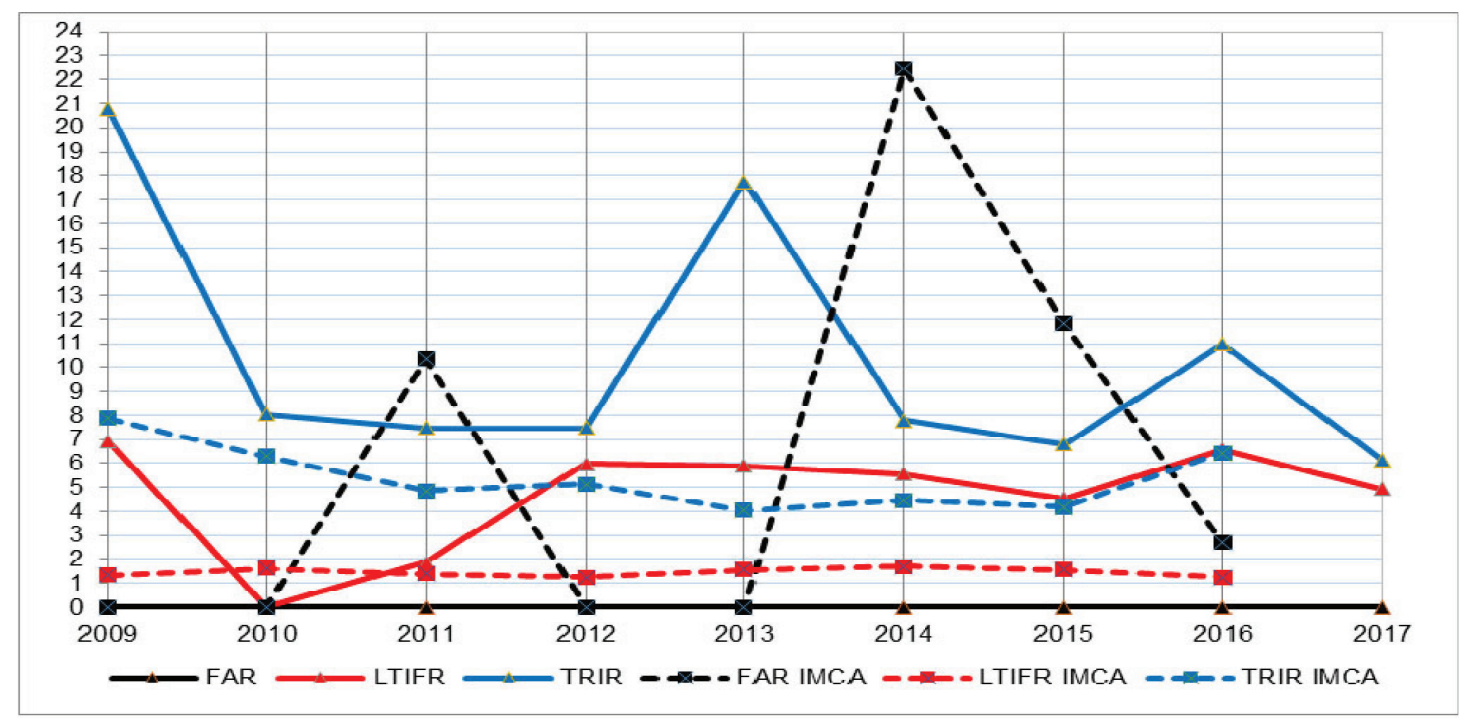

Graph 1 IMCA ( $=264$ ) compared to the selected offshore company: accidents from 2009 to 2016, including 2017 for the selected offshore company only

Graf 1. IMCA (N=264) uspoređen sodabranom odobalnom kompanijom: nezgode od godine 2009. do 2016. uključujući 2017. samo za odabrane odobalne kompanije 
the number of accidents that occurred from 01/02/2016 to $31 / 01 / 2017$; the second interval (2) presents the number of accidents that occurred from $01 / 03 / 2016$ to $28 / 02 / 2017$ and so forth, ending with the twelfth interval presenting the number of accidents that occurred from 01/01/2017 to 31/12/2017.

Table 3 Report through time intervals Tablica 3. Izvješće tijekom vremenskih intervala

\begin{tabular}{|c|c|c|c|c|c|c|c|}
\hline Intervals & $\begin{array}{c}\text { Man- } \\
\text { hours }\end{array}$ & TRI & TRIFR & LTI & LTIFR & $\begin{array}{c}\text { IMCA } \\
\text { TRIFR }\end{array}$ & $\begin{array}{c}\text { IMCA } \\
\text { LTIFR }\end{array}$ \\
\hline 1 & 912.324 & 10 & 10.96 & 7 & 7.67 & 6.43 & 1.24 \\
\hline 2 & 912.588 & 9 & 9.86 & 7 & 7.67 & 6.43 & 1.24 \\
\hline 3 & 911.832 & 8 & 8.77 & 6 & 6.58 & 6.43 & 1.24 \\
\hline 4 & 911.496 & 10 & 10.97 & 8 & 8.78 & 6.43 & 1.24 \\
\hline 5 & 910.164 & 10 & 10.99 & 9 & 9.89 & 6.43 & 1.24 \\
\hline 6 & 907.080 & 9 & 9.92 & 8 & 8.82 & 6.43 & 1.24 \\
\hline 7 & 904.572 & 8 & 8.84 & 7 & 7.74 & 6.43 & 1.24 \\
\hline 8 & 902.712 & 8 & 8.86 & 7 & 7.75 & 6.43 & 1.24 \\
\hline 9 & 894.408 & 8 & 8.94 & 7 & 7.83 & 6.43 & 1.24 \\
\hline 10 & 871.992 & 6 & 6.88 & 5 & 5.73 & 6.43 & 1.24 \\
\hline 11 & 842.316 & 5 & 5.94 & 4 & 4.75 & 6.43 & 1.24 \\
\hline 12 & 812.004 & 5 & 6.16 & 4 & 4.93 & 6.43 & 1.24 \\
\hline
\end{tabular}

Graph 2. Shows the correlation of the accident statistics TRIFR for the selected company compared to IMCA results, as well as the reported LTIFR compared to IMCA results.

At the selected offshore company, the supplied LTIFR results closely follow the TRIFR results. However, when compared to the IMCA average, the obtained TRIFR results at the observed company show a much more pronounced deviation whereas the deviation of LTFIR results is less pronounced. The latter values are below IMCA average in the $10^{\text {th }}, 11^{\text {th }}$, and $12^{\text {th }}$ intervals. Table 4 presents detailed accident statistics at the entire IMCA offshore population and the selected offshore company.

Graph 3. compares the data presented in Table 4.

This analysis indicates that the lost working time incident rate (LTIFR) was close to the IMCA average, while the total recordable incident rate including injuries (TRIFR) was much higher than the IMCA average. When observing the data supplied by the selected offshore company, it is noticed that the working time lost due to injuries continuously mirrors the overall injury rate (the curves match), except for December, when the total injury rate is higher than the rate of injuries that cause the loss of working time.

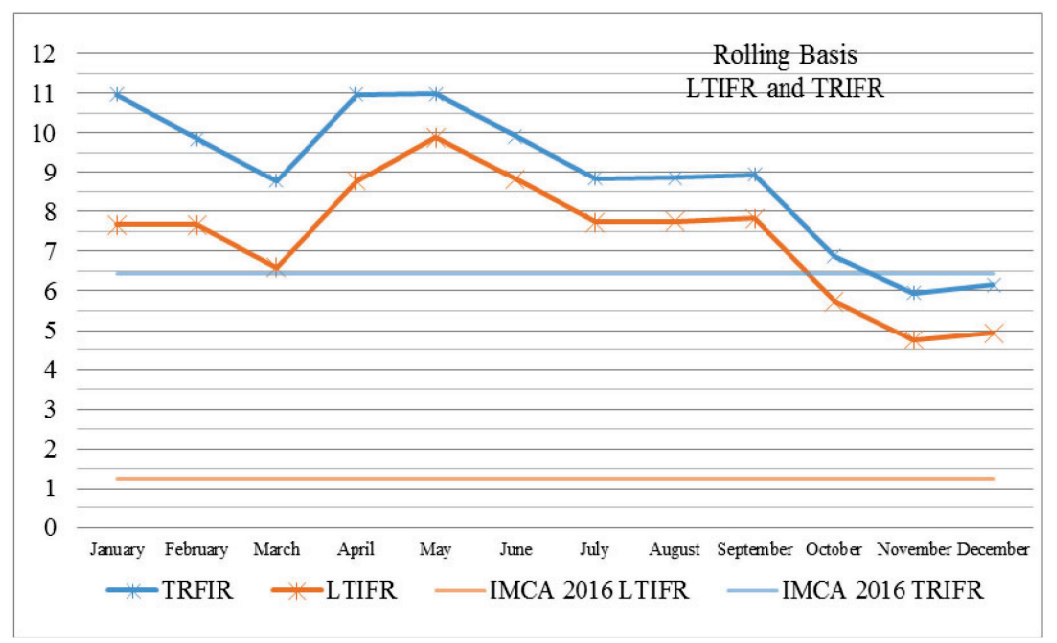

Graph 2 Comparison of accident rates at IMCA and 1 selected offshore company through intervals Graf 2. Usporedba stopa nezgoda kod IMCA i jedna odabrana odobalna kompanija tijekom razdobljâ

Table 4 Monthly data on the total number of accidents in 2017 per man-hours Tablica 4. Mjesečni podatci o ukupnom broju nezgoda u 2017. godini po radnima satima

\begin{tabular}{|c|c|c|c|c|c|c|c|}
\hline Month & Man-hours & TRI & TRIFR & $L T I$ & LTIFR & $\begin{array}{l}\text { IMCA } \\
\text { TRIFR }\end{array}$ & $\begin{array}{l}\text { IMCA } \\
\text { LTIFR }\end{array}$ \\
\hline January & 74.868 & 1 & 13.36 & 1 & 13.36 & 6.43 & 1.24 \\
\hline February & 68.196 & 0 & 6.99 & 0 & 6.99 & 6.43 & 1.24 \\
\hline March & 75.024 & 0 & 4.59 & 0 & 4.59 & 6.43 & 1.24 \\
\hline April & 73.032 & 2 & 10.31 & 2 & 10.31 & 6.43 & 1.24 \\
\hline May & 75.768 & 1 & 10.90 & 1 & 10.90 & 6.43 & 1.24 \\
\hline June & 72.300 & 0 & 9.11 & 0 & 9.11 & 6.43 & 1.24 \\
\hline July & 75.684 & 0 & 7.77 & 0 & 7.77 & 6.43 & 1.24 \\
\hline August & 76.116 & 0 & 6.77 & 0 & 6.77 & 6.43 & 1.24 \\
\hline September & 66.852 & 0 & 6.08 & 0 & 6.08 & 6.43 & 1.24 \\
\hline October & 58.008 & 0 & 5.59 & 0 & 5.59 & 6.43 & 1.24 \\
\hline November & 48.492 & 0 & 5.23 & 0 & 5.23 & 6.43 & 1.24 \\
\hline December & 47.664 & 1 & 6.16 & 0 & 4.93 & 6.43 & 1.24 \\
\hline TOTAL & 812.004 & 5 & 6.16 & 4 & 4.93 & 6.43 & 1.24 \\
\hline
\end{tabular}




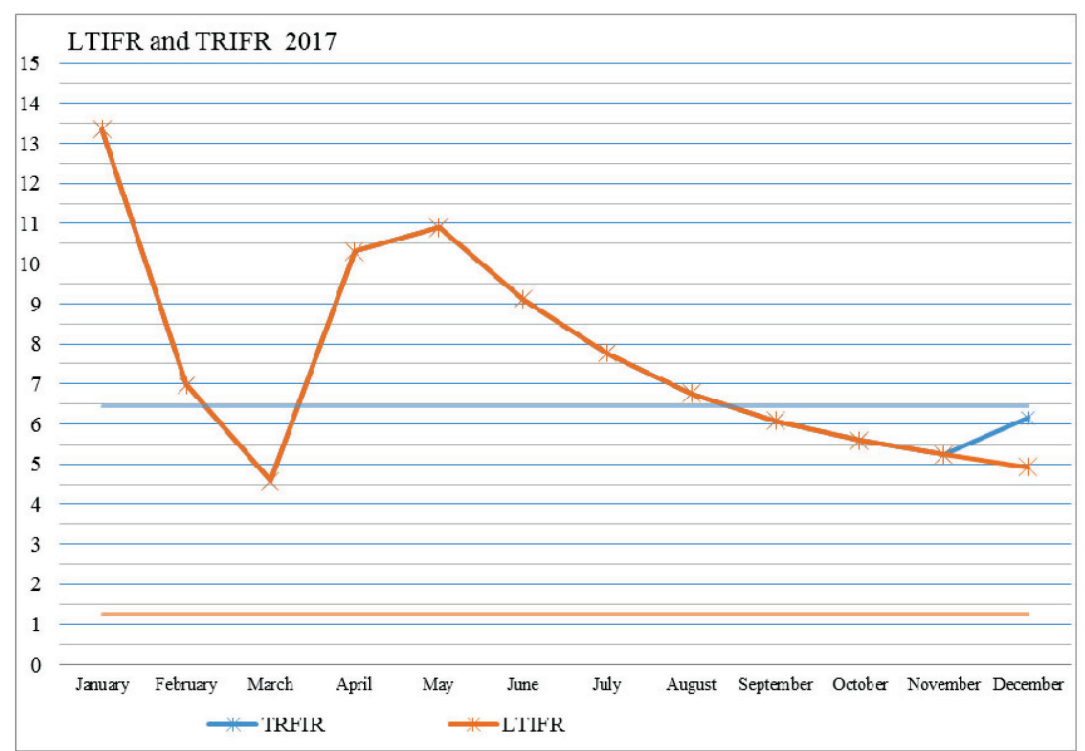

Graph 3 Comparison of the monthly data on the total accidents in 2017 per man-hours Graf 3. Usporedba mjesečnih podataka o ukupnim nezgodama u godini 2017. po radnim satima

\section{DISCUSSION / Rasprava}

The groundwork of this paper is the analysis of the deviations of the statistical data supplied by a selected company with reference to the average of the entire population of companies engaged in the same trade $(\mathrm{N}=264)$, over a defined time interval. The identity of the observed company is protected and is not revealed in this paper. Still, it can be noted that the selected offshore company was established in 2009 and has been engaged in oil rig supplying and towing operations. In the early days the company had three vessels but the fleet gradually increased to reach a sustainable system of 13 vessels from 2012 onwards. The performance analysis indicates that, over the initial period of extensive growth, the company management focused more on operation development than on accident monitoring. It is true that an incident does not necessarily have an impact if it is only recorded and removed. Insights into the available data from the previous years indicate a considerable discrepancy regarding the recorded cases that could have resulted in accidents, i.e. the form of reporting from individual vessels was not standardised. Although efforts were made to introduce higher quality standards, this did not significantly affect the overall business performance assessment with reference to the overall IMCA results. It should also be noticed that the deviations of performance indicators were sometimes very pronounced.

The general quality standard, or the key performance indicator (KPI), has been accepted by world's leading oil

Table 5. KPI of the observed offshore company

Tablica 5. KPI o promatranoj odobalnoj kompaniji (KPI=ključni pokazatelj izvedbe)

\begin{tabular}{|c|c|c|c|c|c|}
\hline & & \multicolumn{4}{|c|}{ Oil spilled into the environment } \\
\hline & & $\begin{array}{l}\text { Pollution of the sea by } \\
\text { cargo }\end{array}$ & $\begin{array}{l}\text { Oil in sea } \\
\quad \text { (in I) }\end{array}$ & $\begin{array}{l}\text { Oil on deck } \\
\text { (in I) }\end{array}$ & $\begin{array}{l}\text { Oil in E/R } \\
\quad \text { (in I) }\end{array}$ \\
\hline \multirow{2}{*}{2009} & Goal & 0 & 0 & $<250$ & $<250$ \\
\hline & Achieved & 0 & 0 & 0 & 0 \\
\hline \multirow{2}{*}{2010} & Goal & 0 & 0 & $<250$ & $<250$ \\
\hline & Achieved & 0 & 0 & 0 & 0 \\
\hline \multirow{2}{*}{2011} & Goal & 0 & 0 & $<250$ & $<250$ \\
\hline & Achieved & 0 & 0 & 8 & 0 \\
\hline \multirow{2}{*}{2012} & Goal & 0 & 0 & 0 & 0 \\
\hline & Achieved & 0 & 0 & 11 & 100 \\
\hline \multirow{2}{*}{2013} & Goal & 0 & 0 & 0 & 0 \\
\hline & Achieved & 0 & 5 & 7 & 0 \\
\hline \multirow{2}{*}{2014} & Goal & 0 & 0 & 0 & 0 \\
\hline & Achieved & 0 & 0 & 100 & 0 \\
\hline \multirow{2}{*}{2015} & Goal & 0 & 0 & 0 & 0 \\
\hline & Achieved & 0 & 50 & 10 & 10 \\
\hline \multirow{2}{*}{2016} & Goal & 0 & 0 & 0 & 0 \\
\hline & Achieved & 0 & 0 & 50 & 400 \\
\hline \multirow{2}{*}{2017} & Goal & 0 & 0 & 0 & 0 \\
\hline & Achieved & & 0 & 0 & 0 \\
\hline
\end{tabular}


companies (Exxon, Shell, BP, Total, Chevron, etc.). This standard of quality implies that all values referring to emission or waste release must be zero. It has been accepted by the maritime offshore company that has been selected and observed for the purpose of this study. The company has complied with the standard since the beginning of the operations and has been keeping relevant records on the release of oil and other harmful substances from their vessels. Table 5 . lists the KPI data. The KPI information consists of reports on loss of cargo, oil spilled into the sea, oil spills on the deck and in the engine room (in litres).

In some intervals, for instance in the year 2014, there were records on the oil spills on the deck and in the engine room. In the beginning, when the company operations started, certain amount of oil spilled onto the deck or in the engine room was tolerable. Just like today, it was essential that nothing was spilled overboard as this would cause pollution of the marine environment. The following table shows that, at the observed company, not much on-board oil spills were recorded over the first three years. However, as the operations grew, the fleet grew accordingly, and the on-board oil spill incidents increased in number, although the amounts were negligible.

Another important indicator of the maritime company performance refers to the number of detentions by the Port State Control (PSC) and to the deficiencies detected by the PSC surveys [8], [9]. Table 6 presents the data on the detected errors/ deficiencies during the PSC inspections. In business documents, this parameter is termed PSC (Port State Control).

Table 6 shows that not a single vessel of the observed company was detained in port due to a serious deficiency. It is obvious that the company has been committed to the quality and technical maintenance of the vessels, so that any detected deficiency could be eliminated on time. It is worth noting that the observed company is also committed to identification and prevention of potential undesired and harmful events by raising and spreading the awareness of the safety at work culture. Over the years, the company adopted the standard implying that the number of "near miss" incidents should not ne less than two per vessel. The number of deficiencies / observations by the Port State Control (PSC) has been determined arbitrarily by a company. It is assumed that the number of inspections and detentions by PSC due to serious deficiencies must be zero, as the detention of a vessel implies a serious loss of time and profit, resulting from disruption of operations and charter party agreements.

The Lost time incident rate (LTIFR) and the Total recordable incident rate (TRIFR) per unit exposure hours are determined at the discretion of a company. Every company has its own criteria with regard to the number of people, number of vessels and the results from the previous periods. At the observed maritime offshore company, the statistical data for the above variables are shown in Table 7.

The goal of every company is to achieve minimum incidents at work. An incident at work implies a potential loss of working time and decrease in workforce productivity. Indeed, the utmost goal is to reduce the Lost time incident rate (LTIFR) to zero. Naturally, this represents one of the key indicators of a company's performance. However, every maritime company has their own standards with reference to the number of employees on board every vessel, the size of the fleet and the results from the previous years. Therefore, the limits of the Total Recordable Incident Rate Frequency (TRIFR) per manhours are set in accordance with individual company standards. A detailed analysis like this allows a company to define its own business and financial construction and to make comparisons with IMCA data.

Since 2012, i.e. the time when the observed company's fleet was completed, the company started to record safety errors that could have resulted in an accident. In order to minimise injuries, damage and Near Miss events [10], [11] the records have to focus on risk assessment, assessment of the situation safety or safety conditions. In practice, this procedure is known as the "Safety Observation" system or, in other words: systematic observation of safety errors that may potentially lead to an accident [12], [13]. The purpose of the Safety Observation system is to raise

Table 6 Number of deficiencies at the vessels of the observed company, detected by PSC from 2009 to 2017

Tablica 6. Broj kvarova na brodovima promatrane kompanije, koje je uočila Lučka državna kontrola od godine 2009. do 2017.

\begin{tabular}{|c|c|c|c|c|}
\hline & & \multicolumn{2}{|c|}{ Port supervision } & \multirow[b]{2}{*}{ NEAR MISS tota } \\
\hline & & Detained in port & Detected deficiencies & \\
\hline 2009 & Goal & 0 & 0 & $>2 /$ vessel \\
\hline \multirow{2}{*}{2010} & Goal & 0 & $<0,5$ & $>2 /$ vessel \\
\hline & Achieved & 0 & 0,82 & 1,7 \\
\hline \multirow{2}{*}{2012} & Goal & 0 & $<0,5$ & $>2 /$ vessel \\
\hline & Achieved & 0 & 2,56 & 0,9 \\
\hline \multirow{2}{*}{2013} & Goal & 0 & $<1$ & $>2 /$ vessel \\
\hline & Achieved & 0 & 3,92 & 0,6 \\
\hline 2015 & Achieved & 0 & 1,15 & 2,7 \\
\hline \multirow{2}{*}{2016} & Goal & 0 & $<1$ & $>2 /$ vessel \\
\hline & Achieved & 0 & 2,00 & 0,5 \\
\hline \multirow{2}{*}{2017} & Goal & 0 & $<1$ & $>2 /$ vessel \\
\hline & Achieved & & 1,33 & 0,5 \\
\hline
\end{tabular}


Table 7 Lost time incident rate (LTIFR) and Total recordable incident rate (TRIFR) per unit exposure hours Tablica 7. Stopa izgubljenoga vremena zbog nezgode i ukupna zabilježena stopa nezgoda po jedinici sata izloženosti

\begin{tabular}{|c|c|c|c|c|c|}
\hline & & \multirow{3}{*}{$\begin{array}{l}\text { LTIFR for 1,000,000 } \\
\text { manhours based on } 12 \\
\text { hours per man / day }\end{array}$} & \multirow{3}{*}{$\begin{array}{l}\text { TRIFR for } 1,000,000 \\
\text { manhours based on } 12 \\
\text { hours per man / day }\end{array}$} & \multirow{2}{*}{\multicolumn{2}{|c|}{ HOURS }} \\
\hline & & & & & \\
\hline & & & & $\begin{array}{l}\text { Day per man based on } \\
12 \mathrm{~h} / \text { day per person }\end{array}$ & $\begin{array}{l}\text { Manhours based on } \\
12 \mathrm{~h} / \text { day per person }\end{array}$ \\
\hline \multirow{2}{*}{2009} & Goal & 0.00 & $<2$ & & \\
\hline & Achieved & 6.2 & 20.75 & 12,051 & 144,612 \\
\hline \multirow{2}{*}{2010} & Goal & 0.00 & $<2$ & & \\
\hline & Achieved & 0.00 & 4.02 & 41,437 & 497,245 \\
\hline \multirow{2}{*}{2011} & Goal & 0.00 & $<2$ & & \\
\hline & Achieved & 1.87 & 7.48 & 44,560 & 534,714 \\
\hline \multirow{2}{*}{2012} & Goal & 0.00 & $<2$ & & \\
\hline & Achieved & 5.99 & 7.48 & 55,691 & 668,292 \\
\hline \multirow{2}{*}{2013} & Goal & 0.00 & $<2$ & & \\
\hline & Achieved & 5.91 & 17.74 & 70,445 & 845,340 \\
\hline \multirow{2}{*}{2014} & Goal & 0.00 & $<2$ & & \\
\hline & Achieved & 0.00 & 7.79 & 74,887 & 898,644 \\
\hline \multirow{2}{*}{2015} & Goal & 0.00 & $<3$ & & \\
\hline & Achieved & 4.54 & 6.81 & 73,381 & 880,572 \\
\hline \multirow{2}{*}{2016} & Goal & 0.00 & $<2$ & & \\
\hline & Achieved & 6.58 & 10.96 & 76,006 & 912,072 \\
\hline \multirow{2}{*}{2017} & Goal & 0.00 & $<2$ & & \\
\hline & Achieved & 4.93 & 6.16 & 67,667 & 812,004 \\
\hline
\end{tabular}

the awareness of onboard safety in advance, which enables the anticipation and prevention of an accident. Table 8 shows that, at the selected maritime offshore company, the number of Safety Observations increased as the company's fleet and experience increased.

Table 8 Number of Safety Observations at the observed company over the years 2012.-2017.

Tablica 8. Broj sigurnosnih opažanja od godine 2012. do 2017.

\begin{tabular}{|c|c|}
\hline Year & Safety Observations \\
\hline 2012 & 245 \\
\hline 2013 & 316 \\
\hline 2014 & 147 \\
\hline 2015 & 382 \\
\hline 2016 & 590 \\
\hline 2017 & 968 \\
\hline
\end{tabular}

According to internal procedures, a safety observation of an event that may cause an accident is reported by the First Mate, but all crew members are obliged to submit an anonymous report on safety errors. These reports are discussed in detail at the Weekly Safety Meeting and the minutes are sent to the socalled Quality Manager on a monthly basis [14].

Records on all safety errors is not aimed at blaming an individual for being responsible for a technical and/or human error but aims at raising awareness of a potential incident and finding ways to avoid such occurrences in the future. It is important to emphasise that one of the reasons for the increased Safety Observations over the past two years resulted from an increased level of safety awareness across the senior officer population.

The observed maritime offshore company has invested considerable funds in training their seafarers in prominent maritime training centres across the world. Every year the company organises a senior fleet officer meeting (SFOM) with a particular focus on safety and raising awareness of onboard safety [15]. Senior officers are required to disseminate the acquired knowledge and experience to junior officers and other crew members.

Table 9. presents the Safety Observations data, including TRI, TRIFR, LTI, and LTIFR on individual vessels operated by the selected offshore company.

A detailed analysis of all the events that may have caused accidents in 2017 indicates that the vessel No. 4 recorded the highest rate of events in 2017. It also shows that there was no accident reported onboard that vessel over that year. The high number of observations can be justified by the increased awareness of safety among the senior officers and their detailed analyses carried out for each individual case. In this way, they paid particular attention to the importance of raising awareness of incidents across the offshore workforce. When observing the vessel No. 11 it can be concluded that detailed records were not kept because their data deviate from the average considerably: there were only 9 safety errors recorded over a period of one year. This implies a conclusion that the level of safety awareness of potential incidents on vessel No. 11 is low, whether due to the scope of operations or senior officers' negligence, and that the safety awareness must be enhanced. When studying the data presented in the table, it becomes obvious that the Safety Observation system was not implemented properly on board vessel No. 11; there were no accidents reported in 2017, while only 9 potentially dangerous situations that may have resulted in an accident were reported.

The same table shows that for the vessels No. 3, 6, 8, 10 and 12 the reports contained only one incident that caused lost time due to injury (TRI) and one event that did not result in loss of time (LTI).

The above discussion makes it clear that keeping records on potential onboard accidents reflects the level of safety awareness of the onboard management and other crew members. It should be underlined that the enhancement of safety awareness on board a vessel is achieved through regular 
Table 9 Rate of recorded safety errors, including TRI, TRIFR, LTI, and LTIFR on board vessels operated by the selected offshore company in 2017 (explanations are below the Table)

Tablica 9. Stopa zabilježenih sigurnosnih grešaka uključujući TRI, TRIFR, LTI i LTIFR na brodovima kojima upravljaju odobalne kompanije u godini 2017. (objašnjenja su u Tablici ispod)

\begin{tabular}{|c|c|c|c|c|c|c|c|c|c|}
\hline 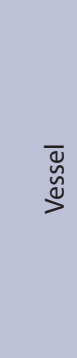 & 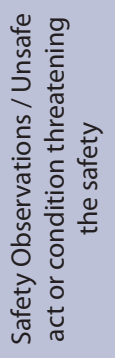 & 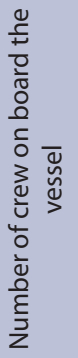 & 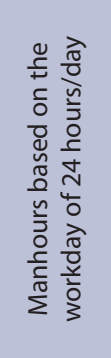 & 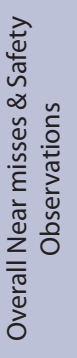 & $\begin{array}{l}\text { 뜬 } \\
\text { o } \\
*\end{array}$ & $\underset{*}{\bar{\kappa}}$ & 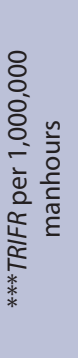 & $\begin{array}{l}E \\
\vec{*} \\
* \\
*\end{array}$ & 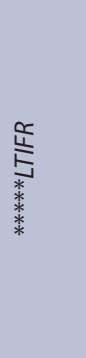 \\
\hline 1 & 49 & 12 & 105,840 & 53 & 1,002 & 0 & 0 & 0 & 0 \\
\hline 2 & 50 & 14 & 119,160 & 50 & 839 & 0 & 0 & 0 & 0 \\
\hline 3 & 36 & 13 & 114,336 & 37 & 647 & 1 & 17 & 1 & 17 \\
\hline 4 & 262 & 14 & 121,968 & 272 & 4,460 & 0 & 0 & 0 & 0 \\
\hline 5 & 93 & 13 & 114,240 & 94 & 1,646 & 0 & 0 & 0 & 0 \\
\hline 6 & 97 & 13 & 114,288 & 102 & 1,785 & 1 & 17 & 1 & 17 \\
\hline 7 & 42 & 12 & 106,392 & 43 & 808 & 0 & 0 & 0 & 0 \\
\hline 8 & 44 & 14 & 121,968 & 44 & 722 & 1 & 16 & 1 & 16 \\
\hline 9 & 79 & 15 & 131,400 & 79 & 1,202 & 0 & 0 & 0 & 0 \\
\hline 10 & 48 & 18 & 155,424 & 50 & 643 & 1 & 13 & 0 & 0 \\
\hline 11 & 9 & 18 & 158,184 & 10 & 126 & 0 & 0 & 0 & 0 \\
\hline 12 & 94 & 14 & 123,072 & 98 & 1,593 & 1 & 16 & 1 & 16 \\
\hline 13 & 65 & 16 & 137,736 & 65 & 944 & 0 & 0 & 0 & 0 \\
\hline \multicolumn{10}{|c|}{ *SOFR - Safety observation frequency rating (per 1,000,000 manhours) Stopa učestalosti sigurnosnih opažanja (po 1.000 .000 radnih sati) } \\
\hline \multicolumn{10}{|c|}{ **TRI - Total number of recordables Ukupan broj zabilježbi } \\
\hline \multicolumn{10}{|c|}{ ***TRIFR per 1,000,000 manhours - Total Recordable Incident Rate Frequence (based on 12 hours per men day) Ukupna zabilježena stopa učestalosti nezgoda (temelj je 12 sati po čovjeku dnevno) } \\
\hline \multicolumn{10}{|c|}{ ****LTI - Lost Time Injuries Izgubljeno vrijeme zbog ozljeda } \\
\hline \multicolumn{10}{|c|}{ *****LTIFR - Lost Time Injury Frequency (per 1,000,000 manhours) Učestalost izgubljenog vremena zbog ozljede (po 1.000 .000 radnih sati) } \\
\hline
\end{tabular}

drills and exercise across the fleet. According to the annual plan, exercise and training activities are performed once a week, typically prior to the weekly safety meeting. A well-trained crew will deal with the situations that may lead to accidents less often, due to increased awareness of hazards involved in everyday tasks. Likewise, it should be noted that, as a rule, a senior officer always makes a risk assessment prior to performing non-routine tasks, in accordance with the guidelines that the company laid out beforehand. If a risk assessment for a certain task does not exist, it must be carried out by the master or the head of deck/engine room. The performance of risk assessment is then followed by an obligatory Toolbox Talk (TBT) where the foreman or head of department discusses the assessed risk with his team, and the performance of the task is planned in detail to prevent any potentially hazardous situation [16]. If a potential hazard is anticipated during risk assessment, the task is suspended or delayed, and cannot be performed until risk assessment process starts anew [17]. All these measures are aimed at accident reduction. Similar practice is implemented at other offshore companies as well, as it has been proven that the companies that efficiently control potential risks (the risks they can affect) attract clients easier and have a higher standing on the competitive international market.

\section{CONCLUSION / Zaključak}

The analysis of accidents at maritime offshore companies provides an insight into the inter-disciplinary quality of the issue. Maritime offshore companies make a segment of the overall maritime transport and are categorised among the companies operating special-purpose vessels that are engaged in a variety of tasks associated with the exploitation of crude oil and natural gas. The safety of performing these tasks has demanding requirements and, as a result, the offshore companies are regarded as high-risk operators whose activities and resources may, under certain conditions, present a threat to the environment, people and property.

The paper describes and discusses the essential safety factors in maritime transport. It has been pointed out that, in most cases, the risk of accident relates to human activities and capacities, i.e. to the employees who perform various tasks in specific segments of maritime transport. Another important factor is the very vessel that is engaged in specific operations, as its inherent features introduce certain deviations into the system of marine environment (ballast waters, safety materials having negative impacts, type of cargo, waste and so forth). There are numerous risk factors in maritime transport, but a proper organisation of activities and educated and welltrained workforce are able to prevent undesired effects. Every company has its own way of raising awareness of safety at work, but all of them have to comply with a number of national and international rules, regulations and conventions in effect. The most frequent cause of safety errors lies in other prevailing interests such as economic profit, which tends to emphasise the involved risks to a lesser extent. When a problem occurs, the responsibility is typically interpreted in public in the most possible acceptable way, although the consequences of errors 
have no ecological, social or economic justification.

The promotion of safety measures implementation has given birth to organisations that specialise in specific issues. On the basis of experience and interpretation of regulations and legislation they raise awareness across the target populations. The agency IMCA was established to enhance the performance of maritime companies. On a voluntary basis, offshore companies are expected to file a report on accidents annually. IMCA uses these data to carry out a statistical analysis for all companies operating in a specific trade. Individual companies can then use the processed data to compare their performance indicators with other companies in the trade, and to focus on deviations and corrections.

One offshore company has been selected for observation in this study. Although its identity has been protected, the data imply that the company has experienced an intensive growth over several years and now operates 13 vessels. It is worth noting that, during the period of expansion, the company management focused more on growth and less on accident monitoring. It is true that an incident does not necessarily have an impact if it is only recorded and removed. Although efforts were made to introduce higher quality standards, this did not significantly affect the overall business performance assessment with reference to the overall IMCA results. It should also be noticed that the deviations of performance indicators were sometimes very pronounced at the observed company.

Finally, it can be concluded that the transparency of operations and the performance based on the principles of responsible management have become an imperative. It is true that every error in performance may not and cannot be interpreted on equal basis, but it is clear that the accidents resulting in environment pollution, property damage, injuries or loss of life, produce negative publicity and affect a company's standing in public and on the global competitive market.

\section{REFERENCES / Literatura}

[1] Scand, J. (1994) Association between safety and contingency measures and occupational accidents on offshore petroleum platforms, Work Enviroment Health, pp. 128-131.

[2] Guidance on permit to work systems in the petroleum industry.1997.ISBN 0717612813, HSE books; [accessed 2018 Feb 20]. http://www.hse.gov.uk/ pUbns/priced/hsg250.pdf

[3] Petrovic, M. (2005) Prevention of sea pollution from ships with purpose of human environment preservation, Pomorstvo, Vol 19, pp. 321-324.

[4] Zec, D. (2001) Safety at sea, Faculty of Maritime Studies in Rijeka

[5] Internal documentation of the Offshore companies, 2009.-2017. (Protected information given for scientific researching).

[6] IMCA internal records. (Protected information given for scientific researching).

[7] Stanivuk, T. (2012) Accident statistics in the chosen offshore company in relation to the other offshore companies. In: Proceedings of the XIII International conference on "Innovative technologies in the function of addressing traffic and environmental problems of the countries in transition", International University Travnik, pp. 53-61.

[8] Tsou, M. C. (2018) Big data analysis of port state control ship detention database. Journal of Marine Engineering \& Technology. Institute of Marine Engineering, Science \& Technology.

[9] Emecen Kara, E. G., Oksas, O. A. (2016) Comparative analysis of regional agreements on Port State Control. American scientific research journal for Engineering, Technology and Science, Vol (18) no.1 pp. 259-260.

[10] Storgard J., Erdogan I., Lappalainen J., Tapaninen U. (2012) Developing incident and near miss reporting in the maritime industry - a case study on the Baltic Sea, Elsevier, Social and behavioural sciences, Vol.48, pp. 1013-1014.

[11] London P., Weaver P., Fitch J.P. (2016) Tracking minor and near-miss events and sharing lessons learned as a way to prevent accidents, Journal of ABSA International, Vol.21 (2), pp. 61-62. https://doi. org/10.1177/1535676016646642

[12] Faturchman D., Mustafa S. (2012) Performance of safety sea transportation Elsevier, International conference on Asia Pacific Business Innovation and Technology Management, Procedia-Social and Behavioral Science 57, pp. 369.

[13] Heij C., Bijward, G. E., Knapp S. (2011) Ship inspection strategies: Effects on maritime safety and environmental protection, Transportation Research Part D 16, Elsevier, pp. 43.

[14] Batalden, B. M. Sydnes, A. K. (2014) Maritime safety and the ISM code: a study of investigated casualties and incidents, WMU J Marit Affairs13, pp. 3-4.

[15] Belev, B. (2016) Fleet officer's seminars as a part of lifelong learning process, Trans Nav, The international journal on marine navigation and safety of sea transportation, Vol 10, number 4.

[16] Talley, W. K. (2013) Maritime transportation research: topics and methodologies, Maritime policy \& management, Vol (40), no.7, pp. 709-710.

[17] Det Norske Veritas for Health and Safety Executive, offshore technology report 2001/063 (2002) HSE books, London, United Kingdom, p. 12-13. 